\title{
Clostridium sordellii
}

National Cancer Institute

\section{Source}

National Cancer Institute. Clostridium sordellii. NCI Thesaurus. Code C86293.

A species of anaerobic, Gram positive, rod shaped bacteria assigned to the phylum

Firmicutes. This species is variably motile by peritrichous flagella, endosporeforming,

catalase and lipase negative and nearly all strains do not ferment maltose. C. sordelli is a

rare human pathogen, causing toxic shock syndrome most often associated with

gynecological infections in females. 